\title{
The Bible's Cultural Mandate, Child Witches, Cognitive Authority, and Christian Pastors
}

\author{
Robert Guy McKee
}

First, I thank the authors-Priest, Ngolo, and Stabell (hereafter, Priest et al.)-and all others concerned, especially the 713 pastors surveyed, for the tremendous work behind this article (2020). I think it not only an invaluable substantive prod to continue a vitally needed conversation, but also a solid theological-anthropological contribution to the same. May God, revealing whatever its dross, use its gold to help deliver many from the shamefully horrific consequences of childwitch allegations.

My contribution to our conversation is that of a Christian anthropologist who thinks that, according to Scripture, created humankind, by God's command, has created and continues to create their cultures, and that they have done and continue to do so either legitimately, reverently to God's glory or illegitimately, irreverently to God's shame. This, at heart, is the idea of the cultural mandate, as grounded especially in Genesis 1:28 and 2:19-20a. ${ }^{1}$ It is a core idea of my own Christian anthropology, ${ }^{2}$ which I began to develop during my Ph.D. studies at the University of Rochester in the $1980 \mathrm{~s}^{3}$ and have been able to teach in recent years at Dallas International University. ${ }^{4} \mathrm{Witches}$, according to this Christian anthropology, have phenomenological reality in many of the world's cultures as products of our fallen, inveterately idol-making imaginations; what they (witches) cannot have, since Scripture nowhere has God, the Creator of all things, having created them, is hard, ontological, really-real-in-that-sense reality. Thus, this anthropology has me agreeing with the Congolese theologian to whom Priest et al. refer at one point-the odd man out who, at the 2015 EPED-hosted workshop concerned, would not confirm, to his audience of pastors and other church leaders stunned by his apparent apostasy in this regard, that he recognized witchcraft as real, or some people as really witches able to harm others through their witchcraft (34). In other words, this anthropology deconstructs witches as utterly incapable of the kinds of harm of which nearly all saidworkshop attendees apparently believe(d) witches indeed capable; it has me disbelieving completely in any ontological reality or power of witches to cause harm; it has me denying categorically the possibility of witch causality. And this goes for child witches, as for any other such special category; and it goes for African witches as alleged sui generis African reality, as for any other such alleged sui generis reality.

Before I would grant, however, that I have now, by publicly reaffirming such a view, ${ }^{5}$ cemented loss of all credibility/cognitive authority on witch-related matters with even a vast majority of African Christian church leaders, permit me to add, please, what I will not accept

\footnotetext{
See, e.g., Waltke (2007, 220-221), Morris (1984, 41-44), Pearcey (2005, 47-49).

Christian anthropology, germanely here, is not the same as Christian-perspective anthropology. The former, grounded explicitly in the Bible, is a different kind of anthropology than secular-humanistic anthropology (normally not marked as to religious-philosophical commitment); the latter is simply open about its Christian perspective within the secular discipline. Meneses (2000) and McKee (2014) exemplify the former; Howell and Paris (2019) exemplifies the latter, while also noting and explaining the difference between the two (2019, 252-254).
}

\footnotetext{
${ }^{3}$ The first paper I wrote about this, I wrote for a theory seminar the second semester of my second year of graduate school. I then attempted to present a conference version of it, twice without success, at annual meetings of the American Anthropological Association. McKee (1998) is what I was eventually able to present at a different professional association's quinquennial meeting.
}

'Formerly, the Graduate Institute of Applied Linguistics, where I have been teaching since 2010.

Please do see McKee (2012), the published form of a 2011 Evangelical Missiological Society conference paper, for the initial widelypublic avowal of my view of witches. 
as reasonably responsible. First, I will not accept the charge of unbelief in supernatural realities-not of ones that $I$ understand to be taught in Scripture; for I definitely do believe in such. Among others, ones in which I do believe are: the one living God; demons/fallen angels, with Satan as chief among them; ${ }^{6}$ angels; miracles-e.g., of healing; spiritual gifts-e.g., of teaching; heaven and hell. ${ }^{7}$ The reason I believe in all these is, I see each taught amply enough in Scripture. Conversely, the reason I do not believe in any supernatural reality to witches or witchcraft is, I do not see witches taught in Scripture, not other than via the type of manmade, powerless idols-i.e., not other than as an imaginable-though-absent-from-Scripture token of a manmade-idol type. In this regard, I am more than persuaded by Priest et al.'s translation/ interpretation of kashaph in Exodus 22:18, not as "witch" or any other kind of "evil secret killer" capable of harming others by their supernatural power, but rather as some kind of public magico-religious professional "with an identity similar to that of African diviners and traditional healers" (43-44).

Second, I will not, as reasonably responsible for loss of cognitive authority in our discussion, accept any charge that is ad hominem attack rather than wellreasoned rebuttal argument. An example at hand of such a charge is "capitulation to white secularist unbelief" (34). ${ }^{8}$ While I reject this, in any case, as untrue of me as represented by the witches-as-idols deconstruction of McKee (2012), its disqualifying logical flaw is it fails to engage the argument and instead attacks the person. Entertained seriously, this could hardly object to such like ad hominem countercharges as, e.g., "clinging to black African-traditional-religious superstition" (my invention, for the sake of the argument here). Scholarly discussion, I respectfully submit, should be above such. Our Congolese theologian colleague deserves better, as do Priest et al. for arguing as they have against any "evil secret killer" translation/interpretation of kashaph in Exodus 22:18. They have reasoned cogently from Scripture for the "public magico-religious professional" translation/ interpretation they recommend (43-45). Further, they do not declare themselves as among those who "categorically deny the very possibility of witch causality" (34). More than reasonably, then, their translation/interpretation must be granted place in the discussion. ${ }^{9}$ In any case, what Scripture says, if anything, about witchcraft and witches, is what should be authoritative in our discussion, and it is this that pastors and other church leaders need to learn and teach, in Africa and around the world.

As discernible above, my theological-anthropological path to not believing in any supernatural reality to witchcraft or witches has been greatly influenced by the cultural mandate. This mandate, as I understand it, has God commanding humankind to construct, to His glory, their cultures. (God does not present the world's peoples with their cultures; for the greatest part, we make them, in obedience to the mandate, whether or not consciously.) Wherever, then, in any of our cultural constructs, we ascribe to created things attributes God did not give them, or, more generally, wherever we fail to ascribe to God alone the glory ${ }^{10}$ due His name, we turn God's glory into shame, loving delusions and lies of our own creation (Ps 4:2). According to the mandate, we must not construct our cultures or cultural-scientific knowledge so; we have no right, before the one living God at the center of the garden, in whose face we respond to the mandate, to do so.

Thus, to start with transgender as an unrelated (and also controversial, I realize) example, we have no right to take "[t]he biblical reality of male and female created by God" and, ascribing attributes of one sex/gender to the other, replace that reality by "the idea that a surgeon's knife and cross-sex hormones can make anyone into the gender of their choice." This is because that replacement idea is ours; it certainly was not God's design or work in His creation; it is impossible, in any case, to thereby "change a man into a woman or vice versa” (Heyer 2019).

Thus also, closer to witchcraft and witches, we have no right to ascribe divinity to the sun, moon, stars, or any other part of God's creation, with such ascription a step preliminary to worshiping them-yet that is how all such false gods/idols are made. And, very importantly, "Like a scarecrow in a melon patch, their [i.e., the nations'] idols cannot speak; they must be carried

\footnotetext{
${ }^{6}$ As regards simply the supernatural reality of demons, I think Lewis (1982) wonderfully instructive.

On miracles, I like, theologically, both Lewis (2015) and Metaxas (2014).

${ }^{8}$ A similar, overlapping charge, which I confront as a red herring in McKee (2012), is that of "Western rationalistic failure to understand 'African realities"” $(2012,18)$. This charge, too, is ad hominem attack rather than well-reasoned rebuttal.

${ }^{9}$ This argument strikes me as Priest at his missiological-anthropological best. Whoever its source, I believe the discussion will do itself a grave disservice if it does not duly appreciate the strength of the theological-anthropological argument here.
}

${ }^{10}$ Not to mention the power, wealth, wisdom, strength, honor, praise, worship, greatness, majesty, splendor, and all else, biblically, that is His due. 
because they cannot walk. Do not fear them; they can do no harm nor can they do any good" (Jer 10:5 NIV 1984). ${ }^{11}$ God did not create anything to be worshiped; worship belongs to God alone. It is not God who created any of human history's innumerable false gods/ idols; rather, very clearly, it is we who have created them all.

Thus finally, hitting home now, we have no right, even in our respective cultures' most well-intentioned efforts to explain misfortune, sickness, and death, to imaginatively-discursively create any witchcraft/ witch power, nor, further, ascribing it to whichever category $/$-ies) of human persons, to create thereby witches and witch causality-yet that is precisely how all witchcraft and evil secret (via witch causality) killers have come to be.

Helpfully here, before exemplifying this last with Mangbetu (Democratic Republic of the Congo) ${ }^{12}$ witchcraft ideas, let us remember several clear biblical truths:

1. By the end of the creation week of Genesis 1, God completed His work of creation. Thus, no created thing, Satan included, has created anything besides what God created in the beginning (Gn 1:1, 2:1-2a; Col 1:16). Also, there is no suggestion anywhere in Scripture that God created witchcraft; and humankind can only ever speak into existence/ discursively construct phenomenological reality.

2. All that God made, including humankind, He saw was very good (Gn 1:31).

3. All of humankind, by Adam's sin, acquired a sin nature (e.g., Rom 5:12, 7:25); the Bible nowhere says, implies, or even allows that humankind or any part thereof thereby acquired witchcraft, its potential, or anything of the sort.

4. God alone is to be feared/revered/worshiped (e.g., Ex 34:14, Ps 96:1-9, Jer 10:1-16, Mt 4:10, Rv 22:9).

The Mangbetu peoples acquired much of their complex of witchcraft, oracles, and magic by borrowing from the Azande. ${ }^{13}$ When I first encountered
Mangbetu witchcraft ideas in the 1980s, they included each of the following:

- that its power rested in an organic, gourd-shaped, luminescent appendage on the small intestine;

- that this appendage, called nótú in Mangbetu, was inherited unavoidably in both same-sex linesmeaning, if a child's same-sex parent was a witch, so, unavoidably, were they;

- that it commanded its bearer to bewitch their victim;

- that its power caused wasting sickness, which, if not effectively countered, ended in the victim's death;

- that its luminescence gave evidence, at a distance, of a witch walking about at night, by this witch light emanating from their mouth and anus;

- that it was discoverable on autopsy.

Biblically, including by the mandate, I do not see any ground for our believing that these or any other such witch-related ideas could ever have ontological reality; rather, I see great reason to recognize them as manmade, God-shaming constructs, capable of any harm or good only as we would idolize-create idolatrously-and effectively fear/worship them as realities. God did not make them; neither Satan nor any other created person or thing has the power to make them; we made them, such as they are-imaginary cultural phenomena; cultural constructs (as opposed to God-created ontological reality). We deal with differing "realities" around the world because they are differing cultural constructions; Scripture nowhere has God having created differing sui generis realities for this continent and that, such that African ontological realities are or can possibly be different from those of any other part of the world. Bolivia's Siriono do not have witches, while the Democratic Republic of the Congo's Mangbetu do, as a matter of cultural difference. Satan, father of lies that he is, behind these and every other God-shaming cultural scene, surely delights to wreak all the havoc, misery, and destruction of which he is capable; what he cannot/does not have the power to do is to effectively change the nature of any of God's creatures by imbuing it with any

\footnotetext{
" "[N]or can they do any good"-not to be overlooked here-evidences biblical proscription of "white" (protective, benevolent) witchcraft as well as "black," since it too is idolatrous.

${ }^{12}$ I simplify here by my use of "Mangbetu"; what I studied more narrowly for my dissertation (McKee 1995), I called there "MejeMangbetu" and have since come to call "Meegye-Mangbetu." My Ph.D. studies of Mangbetu grew out of languacultural interests from my first of two terms of SIL-assisted Mangbetu language project involvement, ca. November 1980-July 1983.

${ }^{13}$ Concerning Zande and Mangbetu witchcraft, oracles, and magic, see, respectively, Evans-Pritchard (1937) and McKee (1995, 467468). The former, in my view, is a true classic of British social anthropology; the latter is an appendix mention, in a dissertation on basically unrelated subject matter, of Meegye-Mangbetu witchcraft, oracles, and magic.
} 
attribute(s) that God did not give it at creation. In sum, Satan cannot, biblically, make people into witches.

And how are pastors and other church leaders to act in all this, assuming they conclude they can do so biblically? Whatever their title or particular ministry, they must stop functioning as shaman-diviner pastors and leaders, especially if, as shaman, they sometimes abuse and even kill ${ }^{14}$ alleged child witches, not one of whom is a witch at all, and because divination is so clearly proscribed biblically. ${ }^{15}$ They must learn and teach faithfully from Scripture witches as manmade idols-as scarecrow idols that no one need fear, as worthless idols that can do neither harm nor good.

To summarize: It is the Bible's cultural mandate and other Scripture, not white secularist unbelief, that deconstructs the idea of witches generally, showing alleged child witches to be innocent victims of illegitimate, God-shaming cultural construction, not real witches capable of supernatural misfortune or harm to others. To surely prevent all wrongful abuse of alleged child witches, Scripture, understood as teaching thus, must be the cognitive authority Christian pastors trust. Hopefully, Priest et al.'s finding that "pastors with formal advanced theological education were less likely to endorse [child-witch] accusations than were pastors whose only training was informal in the context of church ministry" will prove a giant step toward this end.

\section{Bibliography}

Brown, Michael Fobes. 1989. Dark Side of the Shaman. Natural History 98(11):8-10.

Evans-Pritchard, E. E. 1937. Witchcraft, Oracles and Magic among the Azande. Oxford, UK: Clarendon.

Heyer, Walt. 2019. Pastor Jeff Looked at Me through the Eyes of God. Public Discourse. November 18. https://www.thepublicdiscourse.com/2019/11/58390/

Accessed November 20, 2019.

Howell, Brian M., and Jenell Paris. Introducing Cultural Anthropology: A Christian Perspective. 2nd ed. Grand Rapids, MI: Baker Academic.

Lewis, C. S. 1982 (orig. 1942). The Screwtape Letters. Rev. ed. New York: Macmillan.

—— 2015 (orig. 1947). Miracles. Rev. ed. New York: HarperOne.

McKee, Robert Guy. 1995. Meje-Mangbetu (Northeastern Zaire) Death Compensations as Intergroup Rites of Passage: A Structural, Cultural, and Linguistic Study.
Ph.D. dissertation submitted to the University of Rochester, Rochester, NY.

1998. Early Genesis Myth and Judeo-Christian Knowledge. Paper, 14th International Congress of Anthropological and Ethnological Sciences, July 26August 1, Williamsburg, VA.

- 2012. Missiology, the Witch, and the Idol: "Ascribe to the LORD glory and strength," or, The Garden Limit on Humanity's Creative License. GIALens 6(2):1-25. https://www.diu.edu/documents/gialens/Vol6-2/McKee_ Missiology-1.pdf

Accessed November 13, 2019.

. 2014. Destination: Christian Anthropology. Paper, 74th Annual Meeting of the Society for Applied Anthropology, March 18-22, Albuquerque, NM.

Meneses, Eloise Hiebert. 2000. No Other Foundation: Establishing a Christian Anthropology. Christian Scholar's Review 29(3):531-549.

Metaxas, Eric. 2014. Miracles: What They Are, Why They Happen, and How They Can Change Your Life. New York: Plume.

Morris, Henry M. 1984. The Biblical Basis for Modern Science. Grand Rapids, MI: Baker.

Pearcey, Nancy R. 2005. Total Truth: Liberating Christianity from Its Cultural Captivity. Study Guide Edition. Wheaton, IL: Crossway.

Priest, Robert J., Abel Ngolo and Timothy Stabell. 2020. Christian Pastors and Alleged Child Witches in Kinshasa, DRC. On Knowing Humanity Journal 4(1):1-51.

Waltke, Bruce K. 2007. An Old Testament Theology: An Exegetical, Canonical, and Thematic Approach. With Charles Yu. Grand Rapids, MI: Zondervan.

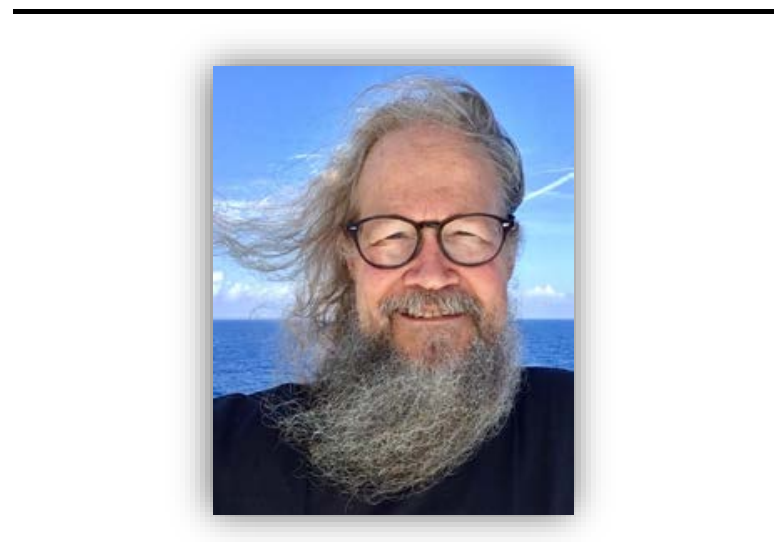

Rob McKee is currently Senior Faculty at Dallas International University. He came to DIU in 2010

\footnotetext{
"See Brown (1989) for a widely-known example, from Aguaruna (Peru), of the "dark" side of shamanism.

${ }^{15}$ See, e.g., Leviticus 19:26, Deuteronomy 18:10, 1 Samuel 15:23, 2 Chronicles 33:6, Jeremiah 14:14.
} 
as Assistant Professor, when the school was still the Graduate Institute of Applied Linguistics. He has an AB (1975) in Social Relations from Harvard, an MA (1985) and PhD (1995) in Anthropology from the University of Rochester (NY, USA). Before coming to DIU, he and his family were nineteen years in Africa with SIL International. His main current topics of professional interest are MeegyeMangbetu (northeastern Democratic Republic of the Congo) studies, Christian anthropology, and lynchings in Kenya.

Author email: rob_mckee@diu.edu 